\title{
ASSESSMENT OF THE APPLICABILITY OF THE BALANCED SCORECARD CONCEPT IN SMALL AND MEDIUM-SIZED ENTERPRISES
}

\author{
Ivana Jolovic ${ }^{*}$ \\ Faculty of Technical Sciences, University of Novi Sad, Republic of Serbia \\ Nevena Jolović \\ Institute of Economic Sciences, Belgrade, Republic of Serbia
}

\begin{abstract}
The modern management concept Balanced Scorecard (BSC), thanks to the efficient solutions it offers, draws increasing attention from the management across the globe. BSC is a performance measurement system which unites a traditional, financial perspective with the consumer, internal business processes, and learning and growth perspectives; and provides intelligibility of the company's vision and strategic goals, strengthening of the internal communication of employees, and more efficient realization of key business activities. The implementation of the BSC concept in large enterprises is a quite simple and efficient process, while the procedure of incorporating its postulates into the structure of small and medium-sized enterprises is extremely complex and uncertain. For that reason, the aim of this scientific research is the assessment of the applicability of the BSC in small and medium-sized enterprises, with a simultaneous overview of examples of successful and less successful implementation practices, and the most frequent reasons for non-implementation of the concept itself. The research is inspired by the observation that the world literature has, to a certain extent, neglected the analysis of the application of the BSC concept in small and medium-sized enterprises. The descriptive and comparative method, the technique of analysis and synthesis, as well as analysis of the content of relevant literature of reference, national and foreign authors were used for research purposes. The result of the research is the confirmed assumption that the implementation of the BSC concept in small and medium-sized enterprises is possible but at the same time quite complex and demanding due to the influence of different variables. Accordingly, the recommendations such as that the BSC model should be simplified and burdened with a smaller number of metrics in order to become more applicable in small and mediumsized enterprises were derived in the research.
\end{abstract}

\footnotetext{
*ivanajolovic@uns.ac.rs
} 
Keywords: Balanced Scorecard, BSC, small and medium-sized enterprises, SMEs, performance measurement systems

JEL classification: L25, M10, M40

\section{OCENA PRIMENJIVOSTI BALANCED SCORECARD KONCEPTA U MALIM I SREDNJIM PREDUZEĆIMA}

Sažetak: Savremena upravljačka koncepcija Balanced Scorecard (BSC), zahvaljujući efikasnim rě̌enjima koja nudi, privlači sve veću pažnju svetske menadžment javnosti. BSC je sistem merenja performansi koji objedinjuje tradicionalnu, finansijsku perspektivu sa perspektivama: potrošača, internih poslovnih procesa, učenja i rasta, te omogućava razumevanje vizije $i$ strateških ciljeva preduzeća, jačanje interne komunikacije zaposlenih $i$ efikasnije obavljanje ključnih poslovnih aktivnosti. Implementacija BSC koncepta u velikim preduzećima predstavlja prilično jednostavan $i$ efikasan proces, dok je postupak ugrađivanja njegovih postulata u strukturu malih $i$ srednjih preduzeća izuzetno složen i neizvestan. Iz tog razloga, cilj istraživanja naučnog rada je ocena primenjivosti BSC-a u malim i srednjim preduzećima, uz istovremeno sagledavanje primera uspešnih i manje uspešnih implementacionih praksi i najčešćih razloga neprimenjivanja sâme koncepcije. Istraživanje je inspirisano zapažanjem da je svetska literatura donekle zanemarila analizu primene BSC koncepta u malim $i$ srednjim preduzećima. Za potrebe istraživanja korišćene su: deskriptivna $i$ komparativna metoda, tehnika analize $i$ sinteze, kao $i$ analiza sadržaja relevantne literature referentnih nacionalnih $i$ inostranih autora. Rezultat istraživanja je potvrđena pretpostavka da je implementacija BSC koncepta u malim i srednjim preduzećima moguća, ali istovremeno $i$ prilično kompleksna $i$ zahtevna usled dejstva različitih varijabli. U skladu sa time, u istraživanju su izvedene preporuke da BSC model treba pojednostaviti, opteretiti manjim brojem metrika $i$ na taj način učiniti primenjivijim $u$ preduzećima male i srednje veličine.

Ključne reči: Balanced Scorecard, BSC, mala i srednja preduzeća, MSP, sistemi merenja performansi

\section{INTRODUCTION}

The key to the continuous improvement of an organization's business results lies in its ability to timely assess the degree of realization of set strategic goals and execution of planned business processes - in a word, in the ability to measure its own business performances. Recognizing the importance of constant and consistent measurement of the performance of the key processes 
they conduct, numerous organizations have adopted various performance measurement systems over the last few decades. A system that stands out among others, and which is often characterized by the label of the latest "managerial vogue", is known as the Balanced Scorecard (BSC).

Most authors do not perceive the BSC concept as an ultimate destination but as a continuous process. Empirical studies emphasize the smoothness of the implementation of this concept in large enterprises, which, by using it, gain additional benefits and effects. On the other hand, by analyzing the available studies it can be concluded that the professional public across the globe, and even the creators of this concept, have not paid enough attention to the issue of (un)successful application of this concept in small and medium-sized enterprises. In accordance with the desire for fulfillment of the aforementioned theoretical gap, the subject of the research refers to the examination of the applicability and efficiency of the BSC concept as a modern measurementmanagement-control system in small and medium-sized manufacturing companies. The aim of this scientific research is the assessment of the applicability of the BSC in small and medium-sized enterprises, with a simultaneous overview of examples of successful and less successful implementation practices, as well as highlighting the most frequent reasons for non-implementation of the concept itself.

The research will contribute to a clearer perception of the opportunities and challenges that, in the process of application of the BS card, have been put in front of small and medium-sized market participants for almost three decades. The actuality of the research is corroborated by the fact that the general interest in the nature of the BSC model does not subside, and that this concept has become an integral part of the business strategies of many companies. There is a realistic expectation that the research itself will affect the awareness of ownersmanagers of small and medium-sized enterprises on the importance of applying the BSC concept; the awareness of employees on the importance of their contribution to the realization of the company's business strategy; and the encouragement of the organizations of small and medium size to implement the model within their own strategic frameworks.

Null and alternative research hypothesis are, based on the subject and the aim of the research, and in accordance with the collected available information, defined as follows:

- $\mathrm{H}_{0}$ : The implementation of the BSC concept in small and medium-sized enterprises is possible, but at the same time quite complex and demanding due to the influence of different variables; 
- $\mathrm{H}_{\mathrm{a}}$ : The implementation of the BSC concept in small and medium-sized enterprises is not possible, nor is considered as complex and demanding.

In order to achieve objectivity, reliability, generality, and systematicity as basic methodological postulates (Miljević, 2007), descriptive and comparative method, analysis and synthesis technique, as well as analysis of the content of available domestic and foreign literature, i.e. works of reference of national and foreign authors on the possibility of applying the BSC concept in small and medium-sized manufacturing companies, will be used in this paper.

\section{THE BSC CONCEPT AS A MODERN SYSTEM OF MEASUREMENT, MANAGEMENT, AND CONTROL}

Using the practice of measuring the performances of the company "ECI", which they observed for almost two years, in 1992. the authors Kaplan and Norton in one of their studies presented the idea of merging the financial perspective (the backbone of traditional performance measurement systems) and non-financial perspectives (consumers, internal business processes, learning, and growth) into a unique model of success - a modern system for performance measurement "Balanced Business Scorecard". In their later papers, the mentioned authors omitted the word "business" from the model, so nowadays the model is known under the abbreviated name "Balanced Scorecard" (Hoque, 2014).

The name of the BSC concept reflects the balance that the model provides between the company's short-term and long-term goals, financial and nonfinancial indicators, lagging and leading indicators, as well as between the company's internal and external perspectives of performance (Pešalj, 2006). The BSC can simply be defined as a management tool that provides a framework for translating strategy into concrete actions. This tool provides a set of performance measures, i.e. metrics that monitor the company's progress in relation to the set goals and certain tasks, and for the sake of fulfilling the strategic plans (Gumbus \& Lussier, 2006). Strategic metrics are arranged within a certain number of perspectives that enable consideration of the complexity of the target function of the company, the importance of intangible resources, and the variability of environmental conditions (Pešalj, 2006). These metrics are decomposed to lower levels, most often in the way that there is no horizontal connection between them (Simeunović, Slović \& Radaković, 2015).

The BSC model was originally conceived as a control system for the measurement of performances, i.e. measurement of the effects of applied strategies of the company and its organizational units. Over time, the theorists have developed the concept in the direction of a strategic management system 
that contributes to the realization of the strategy and its translation into actions at different organizational levels (Krstić \& Sekulić, 2013). Therefore, the BSC concept has evolved over time - it has developed through three generations, encompassing the theoretical and practical development of the model itself. Today it can be observed through its three-generational functions - BSC as a performance measurement system, BSC as a strategic management system, and BSC as a control system. These three functions have been studied empirically, experimentally, and as case studies. All of them reflect different forms of applying BSC, both in large, small, and medium-sized enterprises (Basuony, 2014).

As previously noted, the BSC needs to translate the business strategy of economic entities into measurable goals and indicators. The BSC concept as a performance measurement system includes indicators among which balance has been achieved on three bases. It is meant of the balance between external indicators (shareholders and consumers) and internal indicators (critical business processes, innovation, learning, and growth); the balance between indicators of achieved results and indicators of factors (generators) of future performances; and the balance between objective, easily measurable indicators of achieved results and subjective indicators of the result generators (Pešalj, 2006).

However, the BSC is more than a measurement system used for short-term management purposes. Numerous innovative companies also use this model as a system of strategic management and control. Accordingly, the mentioned management system may include management and monitoring processes such as clarifying and decomposing the company's strategy into specific strategic goals and tasks; communicating strategic goals to employees at the operational level so that each employee understands how his activities can contribute to the realization of the company's strategy; planning, setting goals (for a period of 3 to 5 years) and harmonizing strategic initiatives for improving the quality and speed of response through the setting of short-term control benchmarks; and improving strategic feedback and organizational learning at the executive level (Pešalj, 2006).

The fact is, therefore, that the BSC has evolved from managerial reporter to strategic tool used by executive teams for the establishment of a strategy, coordination of the operations, and communication with internal and external environment and stakeholders (Gumbus \& Lussier, 2006). In order for the company's strategy, which is otherwise very general and broadly defined, to serve as a basis for daily decision-making and action, the BSC concept 
translates it into a system of understandable and measurable goals and indicators arranged in four perspectives. These are the financial perspective, the consumer perspective, the internal business processes perspective, and the learning and growth perspective (Pešalj, 2006).

The financial perspective encompasses traditional financial metrics; the consumer perspective reflects the relationship that the organization has established with its current consumers; the internal business processes perspective focuses on the analysis of practices and methods used in the organization during the value creation process, as well as ways in which they can be improved; while the learning and growth perspective prioritizes finding ways to create an environment that is conducive to organizational change, innovation, and growth (Mehralian, Nazari, Nooriparto \& Rasekh, 2017). The first two perspectives reflect the long-term goals of the company, while the other two enable the realization of the aforementioned strategic ambitions.

Table 1

Metrics classified according to affiliation to the perspectives of the BSC concept

\begin{tabular}{|c|c|}
\hline $\begin{array}{c}\text { Perspectives of the } \\
\text { BSC }\end{array}$ & Metrics/Performance measures \\
\hline Financial perspective & $\begin{array}{l}13 \text { metrics: profitability, liquidity, revenue per product, revenue } \\
\text { per employee, contribution margin, level of indebtedness, return } \\
\text { on investment, unit cost, cost minimization, profit maximization, } \\
\text { inventory, total earnings, and level of operating costs. }\end{array}$ \\
\hline $\begin{array}{c}\text { Consumer (customer) } \\
\text { perspective }\end{array}$ & $\begin{array}{l}12 \text { metrics: customer satisfaction, customer loyalty, number of } \\
\text { new customers, market share, brand value, profitability per } \\
\text { customer, revenue per customer, the satisfaction of business } \\
\text { partners, delivery time, responsiveness to customer requirements, } \\
\text { market share growth, and sales maximization. }\end{array}$ \\
\hline $\begin{array}{c}\text { Internal business } \\
\text { processes perspective }\end{array}$ & $\begin{array}{l}14 \text { metrics: new products, new processes, product turnover, } \\
\text { delivery delay, after-sales support, productivity per business unit, } \\
\text { operating cycle, suppliers, supplier responsiveness, flexibility, the } \\
\text { time required to respond to customers, storage time, waste, and } \\
\text { material integration. }\end{array}$ \\
\hline $\begin{array}{l}\text { Learning and growth } \\
\text { perspective }\end{array}$ & $\begin{array}{l}10 \text { metrics: investment in training, investment in technology, } \\
\text { investment in information systems, the level of employee } \\
\text { motivation, employee capability, managerial efficiency, employee } \\
\text { satisfaction, innovative management, number of complaints, and } \\
\text { risk management. }\end{array}$ \\
\hline
\end{tabular}

Note. Authors, according to "Balanced Scorecard Metrics and Specific Supply Chain Roles", by A. A. Cunha-Callado \& L. Jack, 2015, International Journal of Productivity and Performance Management, 64(2), pp. 290-291. 
The financial and the consumer perspective, therefore, represent two key perspectives of the BSC concept (Pešalj, 2006). In the Table 1 classified according to the four perspectives of the BSC, the 49 metrics that can be used in this modern measurement model will be presented.

All presented metrics/performance measures can be included in the BSC model of the company in accordance with the assessment of their significance by the current management team. Nevertheless, Punniyamoorthy and Murali (2008) point out that the BSC should include at least 20 to 25 balanced metrics arranged in the financial and consumer perspective, as well as in the internal business processes and learning and growth perspective. A study by CunhaCallado and Jack (2015) highlights the view of Johanson, Skoog, Backlund, and Almqvist (2006) that the balance between aforementioned perspectives represents a central issue of the BSC concept, but that the achieving of the same does not imply these four perspectives are equally important.

\section{APPLICATION OF THE BSC CONCEPT}

The key question that arises is how long it takes to introduce the BSC concept into an organizational business system. In large enterprises, this multiphase process can take up to several years, while in smaller organizations it usually requires managerial commitment for only six months or less. The process of the BSC implementation, as expected, requires a phased approach and involves making a plan and schedule for all activities (Krstić \& Sekulić, 2013). In this process not only the final result - the making of the BSC model - is the important one, but also continuous management of it. Accordingly, sufficient time should be set aside to adapt the general BSC model to the specific organizational structure, and to ensure a full understanding of the process by all employees. Some of the statements in the literature that suggest that the process of the BSC implementation should actually never end are quite interesting namely, the process should constantly be the subject of modification and improvement (Pešalj, 2006). The average time interval required to pass through all the planned phases and to the timely achievement of the goal - the application of the BSC concept in a particular company - is presented by the following graphic view (Graph 1).

It should be noted that the presented development and application of the BSC model take into account the assumption that the company operates within only one branch and that there exists a strong correlation between its organizational units. In that sense, it is possible to form a BS card system for the company and its organizational units. 


\section{Graph 1}

The time frame of the multiphase process of the BSC concept application in the company

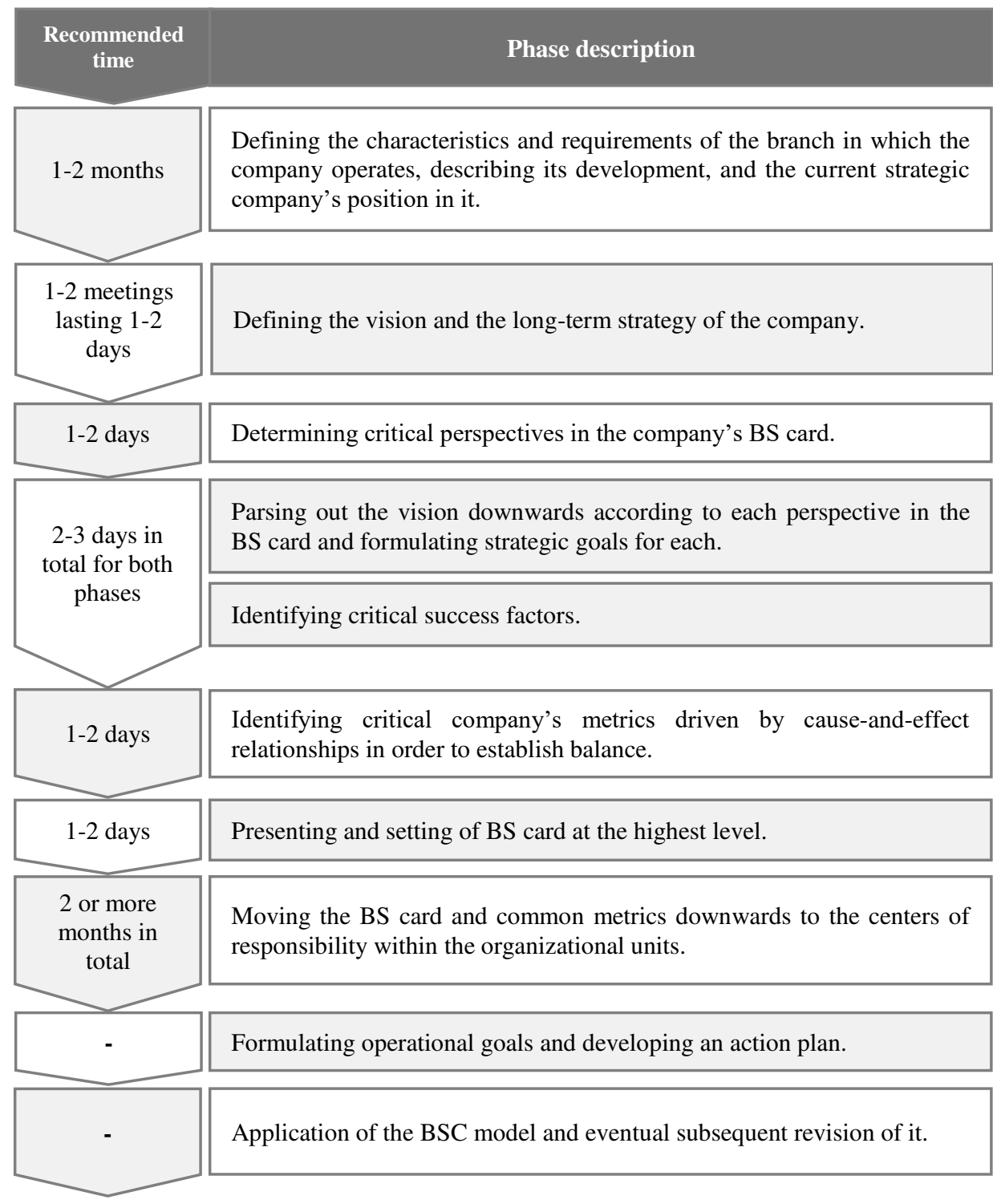

Note. Authors, according to Upravljanje performansama preduzeća (pp. 173-175), by B. D. Krstić \& V. M. Sekulić, 2013, Niš: University of Niš, Faculty of Economics. 
If it is about a complex, highly diversified, and divisionally structured company with business operations related to different activities, the formation of a single, comprehensive BS card at the organizational level is very challenging and difficult (Krstić \& Sekulić, 2013).

\subsection{APPLICATION OF THE BSC CONCEPT IN SMALL AND MEDIUM-SIZED ENTERPRISES}

Theorists had openly stood behind the premise that companies of all sizes are quite good at developing a business mission, but also quite bad at implementing an operational strategy to accomplish the said mission, as well as they are especially bad at assessing (measuring) whether they are actually achieving their mission and strategy. The BSC solves this problem by linking the mission to the company's strategy and then translating the strategy into operational goals and measures. The usefulness of the BSC concept is, therefore, reflected in the fact that it can be used not only by 5 , but even by 5,000 employees working on the achievement of the same goals (Gumbus \& Lussier, 2006).

In one of his studies, Basuony (2014) has critically observed the BSC concept from different perspectives, and through the same, pointed out the most common differences in the implementation of a given model in companies with a small number of employees (small and medium-sized enterprises) on one hand, and companies with a significant number of engaged staff (large enterprises) on the other hand. The aforementioned comparison is presented in the following tabular presentation (Table 2).

In a study by Reynolds, Fourie, and Erasmus (2019), it is pointed out that the BSC can be considered as a useful tool for managing small and medium-sized enterprises, although the procedures of its application in such enterprises may differ significantly from those typical for larger organizations. This view is also confirmed in a study by Singh, Olugu, Musa, and Mahat (2015), in which it is stated that the BSC can be used effectively to assess the performance of small and medium-sized enterprises, taking into account their characteristics. 


\section{Table 2}

Differences in the application of the BSC concept in large, and small and medium-sized enterprises

\begin{tabular}{|c|c|c|}
\hline $\begin{array}{c}\text { Subject of } \\
\text { comparison }\end{array}$ & Large enterprises & $\begin{array}{c}\text { Small and medium-sized } \\
\text { enterprises }\end{array}$ \\
\hline $\begin{array}{l}\text { Application of } \\
\text { the BSC } \\
\text { generation }\end{array}$ & $\begin{array}{l}\text { Application of all BSC generations, } \\
\text { namely: } \\
\text { 1. BSC as a performance measurement } \\
\text { system; } \\
\text { 2. BSC as a strategic management system; } \\
\text { 3. BSC as a control system. }\end{array}$ & $\begin{array}{l}\text { Application of the first and the } \\
\text { second BSC generation only. }\end{array}$ \\
\hline $\begin{array}{l}\text { Used metrics/ } \\
\text { performance } \\
\text { measures }\end{array}$ & $\begin{array}{l}\text { - Required in-depth BS card system that } \\
\text { descends to the level of the unit operational } \\
\text { department; } \\
\text { - The number of metrics ranges from } 18 \text { to } \\
\text { 23; } \\
\text { - Involves a complex process of identifying } \\
\text { and describing the metrics chosen to } \\
\text { inform management about the } \\
\text { organization's progress. }\end{array}$ & $\begin{array}{l}\text { - In-depth BS card system is not } \\
\text { required, but the focus should be } \\
\text { on the breadth of the } \\
\text { organization; } \\
\text { - The number of metrics ranges } \\
\text { from } 5 \text { to } 15 \text {; } \\
\text { - The usefulness of a formal } \\
\text { definition of metrics is lower } \\
\text { than in large enterprises. }\end{array}$ \\
\hline $\begin{array}{l}\text { Application of } \\
\text { the strategy }\end{array}$ & $\begin{array}{l}\text { It is easier to harmonize metrics and } \\
\text { strategic goals. }\end{array}$ & $\begin{array}{l}\text { It is difficult to harmonize } \\
\text { metrics and strategic goals. }\end{array}$ \\
\hline $\begin{array}{l}\text { Design of the } \\
\text { BSC }\end{array}$ & $\begin{array}{l}\text { - The BSC design process is similar to the } \\
\text { one that characterizes small and medium- } \\
\text { sized enterprises; } \\
\text { - The duration of the process is longer than } \\
\text { in small and medium-sized enterprises. }\end{array}$ & $\begin{array}{l}\text { - The BSC design process is } \\
\text { similar to the one that } \\
\text { characterizes large enterprises; } \\
\text { - The duration of the process is } \\
\text { shorter than in large enterprises. }\end{array}$ \\
\hline $\begin{array}{l}\text { Advantages of } \\
\text { the BSC } \\
\text { usage }\end{array}$ & $\begin{array}{l}\text { The potential benefit is realized thanks to } \\
\text { the control role of the BSC in the area of } \\
\text { communication, coordination, feedback, } \\
\text { and subsequent information. }\end{array}$ & $\begin{array}{l}\text { The benefits differ from those in } \\
\text { large enterprises. Through the } \\
\text { BSC, small and medium-sized } \\
\text { enterprises focus on controlling } \\
\text { the strategic vision and } \\
\text { associated strategic goals. }\end{array}$ \\
\hline $\begin{array}{l}\text { Cost-benefit } \\
\text { analysis }\end{array}$ & $\begin{array}{l}\text { They have the ability to cover the costs } \\
\text { incurred due to the application of the BSC } \\
\text { concept. }\end{array}$ & $\begin{array}{l}\text { They do not have the ability to } \\
\text { cover the higher costs incurred } \\
\text { due to the application of the BSC } \\
\text { concept (especially not small } \\
\text { enterprises). }\end{array}$ \\
\hline $\begin{array}{l}\text { Essence of the } \\
\text { BSC }\end{array}$ & $\begin{array}{l}\text { The BSC concept combines financial and } \\
\text { non-financial metrics; short-term and long- } \\
\text { term plans. }\end{array}$ & $\begin{array}{l}\text { The BSC concept seeks to } \\
\text { develop long-term plans and uses } \\
\text { non-financial metrics. }\end{array}$ \\
\hline
\end{tabular}

Note. Authors, according to "The Balanced Scorecard in Large Firms and SMEs: A Critique of the Nature, Value, and Application", by M. A. K. Basuony, 2014, Accounting and Finance Research, 3(2), pp. 19-20. 


\subsection{USEFULNESS OF THE APPLICATION OF THE BSC CONCEPT IN SMALL AND MEDIUM-SIZED ENTERPRISES}

It is well known that the use of the BSC concept in small and medium-sized enterprises significantly differs from the use in large enterprises. Even though the steps that small, medium and large organizations need to take in the process of designing the BS card do not differ much, the fact is that in smaller organizations the duration of taking each step is considerably shorter. In addition, the benefits of adopting the BSC oscillate depending on the type of organization and the way in which that organization applies the aforementioned concept. Large enterprises often realize more benefits effectively communicating their strategy to employees and stakeholders through the BSC model, while small and medium-sized enterprises achieve the same by improving the efficiency of the strategic management process through describing strategic goals and aligning them with priorities (Rompho, 2011).

The continuous use of the BSC creates a platform for a broad assessment of different dimensions of the company. The BSC, for example, improves organizational control by increasing clarity of goals among employees and by creating an accountability structure in which individuals are labeled as those who have metrics at their disposal. More precisely, the managerial commitment to the BSC concept is actually the one that introduces formalization into traditionally informal operational control structures of small and medium-sized enterprises, enabling strategic alignment of employees so that they can effectively follow the set strategy of the company. Furthermore, the use of the BSC for the needs of advanced control initiates regular meetings and discussions between managers and subordinates for the purpose of a more detailed assessment of the information contained in the BSC. These gatherings aim to anticipate possible business outcomes that will result from current activities, and as such represent an opportunity for interpretation and integration of the knowledge for the purpose of converting the achieved efficiency of individual employees into an organizational asset (Malagueño, Lopez-Valeiras \& Gomez-Conde, 2017).

Despite the possibilities that the BSC concept offers, owners-managers should be aware that the use of this method does not automatically improve the company's operations. The BSC concept can be interpreted and used in different ways, which is in practice usually accompanied by serious pitfalls. Nevertheless, a study by Braam and Nijssen (2004) emphasizes that regardless of the manner in which the BSC is used, monitoring the realization of a strategy within it is a key issue for the success of the concept itself. The results of their 
research suggest that the use of the BSC that complements corporate strategy will have a positive impact on business performance. However, the mechanical use of the aforementioned model without a clear link to corporate strategy can become a disruptive factor for achieving performances and/or even a reason for their reduction.

\section{ASSESSMENT OF THE APPLICABILITY OF THE BSC CONCEPT IN SMALL AND MEDIUM-SIZED ENTERPRISES}

The evaluation of the applicability of the BSC concept in small and mediumsized enterprises will be conducted gradually, first by analyzing the issue of success and failure of its implementation, and by corroborating the same with practical examples. The special emphasis of the research will be on the analysis of the reasons for the non-application of this measurement-management-control system in companies of all sizes.

\subsection{SUCCESSFULNESS OF THE APPLICATION OF THE BSC CONCEPT IN SMALL AND MEDIUM-SIZED ENTERPRISES}

BSC is becoming a significant subject of interest in theory and a widely applied concept in practice. This topic is followed by numerous literature publications in which are given examples of successful implementation of the concept in companies that belong to different business sectors. Thus, for example, the study by Fernandes, Raja, and Whalley (2006) highlighted an estimation that about $60 \%$ of the 1,000 "Fortune" companies (1,000 largest U.S. companies ranked by realized revenues) either have adopted or become familiar with the BSC concept. Extensive research conducted by the authors Rigby (2001); Marr, Neely, Bourne, Kennerley, Franco, Wilcox, Adams, and Mason (2004) indicated that $44 \%$ of organizations in North America and 35\% of large U.S. companies use the BSC method. Additionally, numerous expert studies have confirmed that the use of the BSC concept is also widespread throughout the world (Rompho, 2011).

Although these studies support the argument that the BSC concept is widely applied, they do not indicate a fact that the aforementioned model is mainly used in large enterprises. It is certain, therefore, that there is very limited systematic research on the application of the BSC in small and medium-sized enterprises (Fernandes et al., 2006). For this reason, through a review of empirical studies, positive examples of the implementation of the BSC concept in small and medium-sized enterprises will be presented below, and all this for 
the sake of encouraging them to try to apply this modern measurementmanagement-control system.

The first example of successful application of the BSC in small and mediumsized enterprises refers to a study by Malagueño and co-authors (2017) who explored the effects of the BSC usage by small and medium-sized enterprises in terms of financial performances and research innovations. Their observations refer to the increase in efficiency and potential losses in flexibility associated with the formalization of managerial practice in small and medium-sized enterprises. The survey, conducted by the aforementioned authors on a sample of 201 small and medium-sized enterprises in Spain, aimed to find out whether companies that used the BSC as a strategic tool for management and control realized better financial performances and achieved a higher degree of exploitation of innovations. The results of the mentioned study showed that small and medium-sized enterprises benefit from the use of the BSC in controlling and managing the progress of the enterprise and that those which use this method record higher financial performances and exploitative results of innovation than those companies that do not use it. This positive impact on financial performances is stronger at already established small and mediumsized enterprises. Also, the same study provided quantitative empirical evidence that the use of the BSC is an efficient mechanism for an increase of organizational efficiency without any apparent reduction in flexibility (Malagueño et al., 2017).

The second example of successful application of the BSC in small and mediumsized enterprises refers to a study by authors Gumbus and Lussier (2006) which also confirmed that small and medium-sized enterprises can successfully apply the BSC concept, and realize numerous benefits based on its use. That claim is, in the aforementioned research, corroborated by three case studies, and it included the study of three small and medium-sized enterprises - "Hyde Park Electronics", "Futura Industries", and "Southern Gardens Citrus". This research emphasized that more than half of "Fortune 1,000" companies use BSC to improve their own performances, and that, as shown in the example of the three aforementioned enterprises, small and medium-sized organizations can also benefit from the use of this management tool. The implication for entrepreneurs is, therefore, that they also can successfully develop and implement the BSC concept within their borders. The three observed companies, for example, had quite different BS cards which, despite that dissimilarity, worked pretty well in their interest. Consequently, another important implication of this study is that there is no BSC model that could suit everyone, and that, in general, BSCs can be used to encourage thinking about the relative, personalized metrics within the 
framework of critical success factors for any independent business (Gumbus \& Lussier, 2006).

The third example of successful application of the BSC in small and mediumsized enterprises refers to the findings of the authors Dudić, Dudić, Gregus, Novackova, and Đaković (2020) who examined the applicability of the BSC concept in small and medium-sized enterprises as a basis for evaluating innovative activities model in the Slovak Republic and the Republic of Serbia. The research was conducted on a sample of 223 small and medium-sized enterprises that operate across the territories of the two aforementioned countries. The results of the research indicated that the application of the BSC concept in the observed small and medium-sized enterprises was successfully realized, made a positive business impact on all performances of these companies, and empowered not only the company's management but also the employees so they were able to overcome problems and monitor market demand quickly and easily. Yet, in the opinion of the aforementioned authors, the difference between companies from developed and developing countries is evident in terms of ease of application of the BSC model - companies operating in countries in transition are facing more significant obstacles during this process. Nevertheless, the authors maintain the view that the mentioned model is applicable in all companies and all countries, and that its implementation leads to the improvement of the global economy (Dudić et al., 2020).

The fourth example of successful application of the BSC in small and mediumsized enterprises relates to the research conducted by Reynolds and co-authors (2019) who worked on the issue of generic BSC model development which could be applied in small and medium-sized manufacturing companies (in their case, those operating in the territory of South Africa). The findings of the expert team during the development of generic BSC confirmed the assumption that the model itself can be applied in small and medium-sized enterprises, but that it should be adapted and made less complicated and easier to use in order for the enterprises to conduct its implementation successfully. In their opinion, the ability to adapt the generic BSC model (by including sufficient flexibility) to the needs of the aforementioned companies makes this managerial tool outstanding. The authors of the aforementioned study recommend that the owners-managers of small and medium-sized manufacturing companies, with extensive consideration, adapt the generic BSC to the specific key success factors related to their organizations. Also, these authors advise companies to approach the implementation of the BSC concept economically, i.e. to choose easily measurable key success factors that do not require additional resource investments into their calculation processes (Reynolds et al., 2019). 


\subsection{UNSUCCESSFULNESS OF THE APPLICATION OF THE BSC CONCEPT IN SMALL AND MEDIUM-SIZED ENTERPRISES}

Many theorists believe that the main reason for the widespread use of the BSC model, both in large, and small and medium-sized enterprises, lies in the assumption that it can positively affect the performance of enterprises. Previous research on the contribution of BSC to small and medium-sized enterprises has indicated a positive correlation between the BSC implementation and the development of new capabilities and research initiatives of these organizations (Malagueño et al., 2017). However, despite numerous examples of successful implementation of the BSC concept, the authors Kaplan and Norton (2001), according to the research conducted by Rompho (2011), and with the help of several more detailed studies, identified two, as they claim, basic sources of failure of the BSC application in companies. It is about design and process.

In their opinion, a poorly designed BS card can lead to the failure of the implementation of the entire BSC system in the organization. The poor design includes too few metrics presented within each BSC perspective, too many indicators without identifying several critical and key ones, and the "inability" of selected metrics to reflect the organization's strategy itself. On the other hand, poorly implemented processes are the most common causes of failure of the implementation of the entire BSC model and include the insufficient commitment of senior management; too few people engaged; hiring inexperienced expert consultants; keeping the BS card at the top, i.e. "not lowering" it to the levels of unit operational departments; the excessive duration of the BS card development process; treatment of the BSC as a disposable measuring instrument; as well as the introduction of the BSC by management only for the purpose of obtaining financial compensation on that basis (Rompho, 2011).

The causes of the failure of the application of the BSC concept identified in the research publications of the authors Kaplan and Norton can be confirmed and expanded in accordance with the opinions of other authors. For example, Fernandes and co-authors (2006) argue that lack of human resources, rather than financial ones, is one of the main obstacles for the application of the BSC in small and medium-sized enterprises. The author McAdam (2000) adds that the lack of systematic training and development plans for employees disrupts the implementation of the mentioned application process. In addition, the success of the implementation of this process can be affected by additional factors, such as working conditions and overall employee satisfaction; and social issues that include attitudes and behavior, lack of openness and trust of employees 
(Basuony, 2014). Problems in the implementation of the BSC concept could be caused even by the owner-manager, his initial perception of the importance of each goal, factor, or measurable parameter and thus, by the consequent actual implementation of the established strategic goals within the company itself (Kozel, Vilamová, Baránek, Friedrich, Hajduová \& Behún, 2017); and by his individual (in)ability to process a large number of different information in a limited time. This, consequently, can prevent the organization from realizing optimal benefits based on information gathered using the introduced BSC concept (Handoko \& Wehartaty, 2017). In addition, it is believed that the same problem can be encountered and by the owner-manager who shows extreme caution when it comes to sharing business information and strategic plans with employees (Basuony, 2014).

Building on the last, above-mentioned statement it is worth to highlight the view of authors Synek, Dvořáček, Dvořák, Kislingerová and Tomek (2011), presented in a study by Lesáková and Dubcová (2016), that in the process of designing (construction) and application of the BSC model in the company the whole team of experts should work together. Besides, the theoretical knowledge and practical experiences of many companies indicate the indisputable fact that the adequate application of the BSC concept (primarily due to the competencies and authority they possess) in companies of all sizes requires a strong commitment of the highest management levels and their active participation in all systemic activities of the aforementioned application. However, the importance of lower-level managers' commitment to the process of the application of the BSC method is also negligible, as well as the importance of the basic awareness of employees engaged on those levels. Awareness and informing of all employees reduce resistance to change and minimize collective and individual fear of new and unknown (Lesáková \& Dubcová, 2016).

An example of the unsuccessful application of the BSC in small and mediumsized enterprises refers to the research by Rompho (2011) conducted in "SAQ Company Limited", a small-sized enterprise. The aforementioned company ensured the fulfillment of all factors that are listed in the literature as critical for the success of the BSCbut still failed to apply the aforementioned model in practice. Interviews and observations revealed that the main cause of failure were frequent changes of the company's strategy. In this company, since the beginning of the use of the BSC, a series of metrics have either been added or revised. For example, three months after the launch of the BS card, the company's sales fell due to a poor distribution channel. The company sold its products to traders who were also selling the products of competitors. This meant that the aforementioned dealers did not have the right motivation to 
especially encourage the sale of the "SAQ" products. Then, the owner-manager decided to change the distribution channel, moving from distribution through dealers to distribution through supermarkets. The results were impressive, and sales doubled the following month. However, this change has also resulted in changes in several metrics that address the consumer perspective, and in changes in metrics that address the internal business process in a way that reflects modifications in the consumer perspective (Rompho, 2011).

In the aforementioned case study, it was found that the cause of the BSC failure due to the presented changes, however, would not be usual in large organizations. This limitation of the BSC concept is, therefore, specific to the nature of the businesses of small and medium size, where the reactions to market changes are more frequent and greater than in large enterprises that operate on a much more stable market. In the above-mentioned company, thus, over a two-year period, the metrics of the BS card were revised several times due to strategy changes that were inevitable in a rapidly changing business environment. This, however, created confusion, both in the relations among the employees and in the communication between the employees and the ownermanager. Frequent revision of the BSC also required obtaining new data for newly added metrics, which ultimately disabled monitoring of the cause-andeffect relationship of the BS card's metrics and led to the significantly higher expenditures of organizational time and effort. Accordingly, the findings of this case study expand the knowledge base on the application of the BSC, revealing that the factors which, according to the literature, lead to the successful use of this concept in small and medium-sized enterprises, although necessary, are not sufficient and cannot guarantee success. Frequent changes in strategy that require revision of the $\mathrm{BSC}$ are, therefore, another important factor that determines the success or failure of the implementation of the previously mentioned model (Rompho, 2011).

\subsection{REASONS FOR NON-APPLICATION OF THE BSC CONCEPT IN SMALL AND MEDIUM-SIZED ENTERPRISES}

In practice, there often exists a low interest of numerous enterprises to apply the BSC method in their business process. The most common reasons for disinterest in the application of the BSC include incomprehension of the method itself, usage of other strategic management instruments, perceiving the BSC only as a performance management tool, as well as the misperception that the model does not contribute to strategic management (Lesáková \& Dubcová, 2016). 
Compared to large enterprises, small and medium-sized enterprises are fundamentally different in three aspects - uncertainty, innovativeness, and evolution. As a result, the BSC system in small and medium-sized enterprises is somewhat different from the one that exists in large enterprises, in a manner that it is often much more complicated and difficult to implement. In general, small and medium-sized enterprises are usually difficult to involve in performance measurement processes due to lack of free time and/or insufficient involvement of top management in that process. In addition, small and medium-sized enterprises often implement only some parts of a performance measurement system or modify models without carefully examining the impact of such modification. Also, it is confirmed that small and medium-sized enterprises rarely apply a performance measurement system as a holistic approach, that metrics in their models are mainly focused on operational and financial performances, and that they neglect metrics related to non-financial performance indicators (Rompho, 2011).

As it is pointed out at the very beginning, one of the reasons why the BSC model is not applying, either in small or medium-sized enterprises, is that the owners-managers of these organizations are not familiar with it. When formulating a proposal for overcoming the mentioned reason for nonapplication of the BSC, i.e. in order to increase the small and medium-sized enterprises' knowledge about the BSC method, one can start from the preferred company's methods of collecting information. Owners-managers acquire new knowledge mainly through the educational system, i.e. by education through professional training. A significant number of companies, on the other hand, gain new knowledge by studying professional journals and scientific publications, or by analyzing the experiences of other companies - the experiences of the companies with which they cooperate, and/or the experiences of the competitor companies. Also, these companies often have services of specialized agencies at their disposal. More precisely, companies can decide to apply the BSC method independently (internal implementation) or to use the skills of qualified individuals specialized in the mentioned field and the help of consulting agencies for these purposes. The BSC method, therefore, can be applied in different ways, i.e. through various channels (Lesáková \& Dubcová, 2016).

An additional reason why the BSC concept, certain small and medium-sized organizations do not apply in business practice can be found in the observations of several authors related to the use and peculiarities of managerial practice in these companies. In a study by Malagueño and co-authors (2017), some of them are presented. First, as authors Ates, Garengo, Cocca, and Bititci (2013) state, 
resource constraints, especially managerial time and expertise, indicate that management practice routine is much more demanding for small and mediumsized enterprises than for larger organizations, and that application of such concept would further jeopardize their time and possibly bring to light their incompetence. Second, as authors Hudson-Smith and Smith (2007) argue, the lack of a cash security network for small and medium-sized enterprises and their high reliance on few customers obliges their managers to be more careful while developing metrics and covering costs arising from their use. Third, the flexible structure that characterizes small and medium-sized enterprises usually "requires" employees to perform multiple activities and roles, with unclear boundaries and business commitments. This is an obvious deficiency of the quality of management control. In accordance with such management status, there is a fear that with the introduction of new methods, the obligations of employees will increase, and duties will further intertwine, which will in the final instance further aggravate the already unstable position of the company. Finally, the application of the BSC as a formal management practice can easily confuse employees of small and medium-sized enterprises by introducing another, additional layer of control that will subsequently weaken even more the already flexible existing communication and control structures (Malagueño et al., 2017).

Authors Dobrovič, Urbański, Gallo, Benková and Čabinová (2018) in their study highlight the views of the author Onyusheva (2017) who confirms that some of the reasons why small and medium-sized enterprises do not use the BSC concept as a measurement-management-control model include lack of qualified people for its implementation in the management system and the high financial costs for its running. The human resources area, mentioned as a significant factor for non-use of the BSC in smaller organizations, in practice often encompasses the incompetence of the company's employees to apply strategic management principles. In line with this is the interpretation of the author Witek-Crabb (2016), also presented in the aforementioned study, that the ability of managers to implement strategic management principles in smaller companies is significantly lower compared to the ability of employees at the same functions in large organizations to do so. These statements are followed by the results of the scientific research conducted by Tomić, Komazec, and Jevtić (2017), according to which small and medium-sized enterprises that do not apply the BSC agreed that the main reason for the waiver of the application of this method lies in the fact that BSC usage is complicated, expensive, and long-lasting. 
The issue of financial requirements and complexity of the classical BSC concept for small and medium-sized enterprises, according to the current views of the authors Malbašić and Marimon (2019), can be solved through the application of the latest method - the balanced BSC. This measurement system is based on only 25 key performance measures/metrics which can be easily and simply collected since most organizations already use them for daily management. As these authors argue, it is even superfluous to mention the numerous positive managerial implications for small and medium-sized enterprises, which arise from the use of the simplified BSC method. According to the mentioned theorists, these organizations are not able to invest resources in defining a classic, complex BSC, nor they have the ability to adequately apply and monitor its principles. The balanced BSC enables the application and monitoring of an acceptable business model, analysis, and improvement of results, influencing simultaneously the entire "plan-do-check-act" cycle (Malbašić \& Marimon, 2019).

As pointed out in one of the studies conducted by Lonbani, Sofian and Baroto (2016), even the BSC concepts constructed in small and medium-sized enterprises in a less formal and complex way can prove to be very efficient and do equally good a "job" as concepts used by large enterprises. The implementation of the BSC concept, in any case, is not a universal issue that equally reflects on all companies, so it is certain that some of these organizations will always apply it with less, and some with more effort (Benková, Gallo, Balogová \& Nemec, 2020).

\section{CONCLUSION}

Based on the analysis of literature sources and previous empirical studies, i.e. the views presented in the scientific paper, the research can be summarized through the presentation of several significant findings. One of them is that the successfulness of the implementation of the BSC concept in small and mediumsized enterprises depends on the level of awareness, qualifications, and commitment of their human resources since the paper points out that attitudes and behavior of employees, working conditions, and overall job satisfaction, levels of trust and openness of employees; the level of commitment of senior management, (in)ability of managers to process a large amount of information in a limited time; introduction of BSC by the management only for the purpose of obtaining financial compensation on that basis; hiring inexperienced consultants; and an inadequate number of involved people, cumulatively affect the successfulness of the application of the BSC model in practice. 
In addition, it was found that the success of the implementation of the BSC concept in small and medium-sized enterprises is determined by the adequacy of BS card design and the quality of measurement, management, and control processes, since the paper proved that poor BS card design and inadequate processes, more precisely, too few metrics presented within each BSC perspective; too many indicators without identifying several critical and key ones; the "inability" of selected metrics to reflect the organization's strategy itself; and keeping the BS card at the top, i.e. "not lowering" it to the levels of unit operational departments; the excessive duration of the BS card development process; and the treatment of BSC as a disposable measuring instrument, affect the successfulness of the application of the BSC model in practice.

The finding of the conducted research is also that the complexity and a large number of metrics in the BSC model often represent an excessive burden for small and medium-sized enterprises, which either aggravates or prevents the implementation of this concept since, according to many authors (of whom in the paper were mentioned Reynolds, Fourie, Erasmus, Malbašić, and Marimon), the classic BSC concept is too complicated and expensive for small and medium-sized enterprises. More precisely, the above-mentioned organizations are not able to adequately apply and monitor complex BSC models, nor to use a larger number of metrics, since their collection and calculation often cause significant financial and labor costs.

In accordance with all the facts presented in the paper (especially practical examples of successful application of the BSC concept in small and mediumsized enterprises), it is possible to accept the null, i.e. reject the alternative research hypothesis, and conclude that the implementation of the BSC concept in small and medium-sized enterprises is possible, but at the same time quite complex and demanding due to the influence of different variables (such as the level of awareness, qualifications, and commitment of human resources; the adequacy of BS card design and the quality of implementation of measurement, management, and control processes; the complexity and a number of metrics in the BSC model; etc.).

The summary assessment of the applicability of the observed concept is positive. However, the recommendation is to make the BSC model for small and medium-sized enterprises less formal and complex, to burden it with fewer metrics compared to those applied in large enterprises, and thus make it cheaper and more affordable, and therefore more applicable. Another conclusion is that it is worthwhile to invest the organizational time, effort, and resources in the 
entire implementation process since the BSC concept can undoubtedly contribute to improving aspects of organizational control, managerial skills, mutual communication, and realized performances of small and medium-sized enterprises.

\section{REFERENCES}

Ates, A., Garengo, P., Cocca, P., \& Bititci, U. (2013). The Development of SME Managerial Practice for Effective Performance Management. Journal of Small Business and Enterprise Development, 20(1), 28-54.

Basuony, M. A. K. (2014). The Balanced Scorecard in Large Firms and SMEs: A Critique of the Nature, Value, and Application. Accounting and Finance Research, 3(2), 14-22.

Benková, E., Gallo, P., Balogová, B., \& Nemec, J. (2020). Factors Affecting the Use of Balanced Scorecard in Measuring Company Performance. Sustainability, 12(3), 1178-1196.

Braam, G. J. M., \& Nijssen, E. J. (2004). Performance Effects of Using the Balanced Scorecard: A Note on the Dutch Experience. Long Range Planning, 37(4), 335-349.

Cunha-Callado, A. A., \& Jack, L. (2015). Balanced Scorecard Metrics and Specific Supply Chain Roles. International Journal of Productivity and Performance Management, 64(2), 288-300.

Dobrovič, J., Urbański, M., Gallo, P., Benková, E., \& Čabinová, V. (2018). Balanced Scorecard Concept as a Tool of Strategic Management and its Usage in the Construction Industry. Polish Journal of Management Studies, 18(2), 59-72.

Dudić, Z., Dudić, B., Gregus, M., Novackova, D., \& Đaković, I. (2020). The Innovativeness and Usage of the Balanced Scorecard Model in SMEs. Sustainability, 12(8), 3221-3243.

Fernandes, K. J., Raja, V., \& Whalley, A. (2006). Lessons from Implementing the Balanced Scorecard in a Small and Medium-size Manufacturing Organization. Technovation, 26(5-6), 623-634.

Gumbus, A., \& Lussier, R. N. (2006). Entrepreneurs Use a Balanced Scorecard to Translate Strategy into Performance Measures. Journal of Small Business Management, 44(3), 407-425. 
Handoko, J., \& Wehartaty, T. (2017). Strategic Balanced Scorecard Implementation in Controlling Bias and Conflict. Polish Journal of Management Studies, 15(1), 57-65.

Hoque, Z. (2014). 20 Years of Studies on the Balanced Scorecard: Trends, Accomplishments, Gaps, and Opportunities for Future Research. The British Accounting Review, 46(1), 33-59.

Hudson-Smith, M., \& Smith, D. (2007). Implementing Strategically Aligned Performance Measurement in Small Firms. International Journal of Production Economics, 106(2), 393-408.

Johanson, U., Skoog, M., Backlund, A., \& Almqvist, R. (2006). Balancing Dilemmas of the Balanced Scorecard. Accounting, Auditing \& Accountability Journal, 19(6), 842-857.

Kaplan, R. S., \& Norton, D. P. (2001). The Strategy-Focused Organization: How Balanced Scorecard Companies Thrive in the New Business Environment. Boston: Harvard Business School Press.

Kozel, R., Vilamová, Š., Baránek, P., Friedrich, V., Hajduová, Z., \& Behún, M. (2017). Optimizing of the Balanced Scorecard Method for Management of Mining Companies with the Use of Factor Analysis. Acta Montanistica Slovaca, 22(4), 439-447.

Krstić, B. D., \& Sekulić, V. M. (2013). Upravljanje performansama preduzeća. Niš: University of Niš, Faculty of Economics.

Lesáková, L., \& Dubcová, K. (2016). Knowledge and Use of the Balanced Scorecard Method in the Businesses in the Slovak Republic. Procedia Social and Behavioral Sciences, 230, 39-48.

Lonbani, M., Sofian, S., \& Baroto, M. B. (2016). Balanced Scorecard Implementation in SMEs: Addressing the Moderating Role of Environmental Uncertainty. Global Business and Organizational Excellence, 35(3), 58-66.

Malagueño, R., Lopez-Valeiras, E., \& Gomez-Conde, J. (2017). Balanced Scorecard in SMEs: Effects on Innovation and Financial Performance. Small Business Economics, 51(1), 221-244.

Malbašić, I., \& Marimon, F. (2019). A Simplified Balanced "Balanced Scorecard". European Accounting and Management Review, 2(1), 38-60. 
Marr, B., Neely, A., Bourne, M., Kennerley, M., Franco, M., Wilcox, M., Adams, C., \& Mason, S. (2004). Business Performance Measurement What is the State of Use in Large US Firms? In: Neely, A., Kennerley, M., Walters, A. (Eds.), PMA 2004: Public and Private Conference (283290). Cranfield UK: Centre for Business Performance.

McAdam, R. (2000). Quality Models in an SME Context: A Critical Perspective Using a Grounded Approach. International Journal of Quality \& Reliability Management, 17(3), 305-323.

Mehralian, G., Nazari, J. A., Nooriparto, G., \& Rasekh, H. R. (2017). TQM and Organizational Performance Using the Balanced Scorecard Approach. International Journal of Productivity and Performance Management, 66(1), 111-125.

Miljević, I. M. (2007). Metodologija naučnog rada. Pale: University of East Sarajevo, Faculty of Philosophy.

Onyusheva, I. (2017). Analytical and Managerial Issues of Human Capital in Conditions of Global Competitiveness: The Case of Kazakhstan. Polish Journal of Management Studies, 16(2), 198-209.

Pešalj, B. (2006). Merenje performansi preduzeća: Tradicionalni i savremeni sistemi. Belgrade: Publishing Centre of the Faculty of Economics in Belgrade.

Punniyamoorthy, M., \& Murali, R. (2008). Balanced Score for the Balanced Scorecard: A Benchmarking Tool. Benchmark: An International Journal, 15(4), 420-443.

Reynolds, A., Fourie, H., \& Erasmus, L. (2019). A Generic Balanced Scorecard for Small and Medium Manufacturing Enterprises in South Africa. The Southern African Journal of Entrepreneurship and Small Business Management, 11(1), 1-15.

Rigby, D. (2001). Management Tools and Techniques: A Survey. California Management Review, 43(2), 139-160.

Rompho, N. (2011). Why the Balanced Scorecard Fails in SMEs: A Case Study. International Journal of Business and Management, 6(11), 39-46.

Simeunović, B., Slović, D., \& Radaković, J. A. (2015). Analiza modela za merenje performansi procesa. Škola biznisa, 2, 49-64.

Singh, S., Olugu, E. U., Musa, S. N., \& Mahat, A. B. (2015). Fuzzy-based Sustainability Evaluation Method for Manufacturing SMEs Using SCHOOL OF BUSINESS, 1/2020, 112-136 
136 | ASSESSMENT OF THE APPLICABILITY OF THE BALANCED SCORECARD CONCEPT IN SMALL AND MEDIUM-SIZED ENTERPRISES

Balanced Scorecard Framework. Journal of Intelligent Manufacturing, 29(1), 1-18.

Synek, M., Dvořáček, J., Dvořák, J., Kislingerová, E., \& Tomek, G. (2011). Manažérska ekonomika. Praha: Grada Publishing a.s.

Tomić, S., Komazec, Lj., \& Jevtić, J. (2017). The Modern Concept of Measuring Efficiency - Implementation, and Attitudes of BSC. TEM Journal, 6(3), 525-533.

Witek-Crabb, A. (2016). Maturity of Strategic Management in Organizations. Oeconomia Copernicana, 7(4), 669-682.

Delivered: 03.09.2020. Accepted: 27.11.2020.

Note: The realization of the research was supported by the funds of the Ministry of Education, Science and Technological Development of the Republic of Serbia, in accordance with the Scientific Research Program 20192025 of the Faculty of Technical Sciences, University of Novi Sad, and the Scientific Research Program 2019-2023 of the Institute of Economic Sciences in Belgrade. 